UDC 378.091.12:364-78:364-322

DOI: https://doi.org/10.31470/2415-3729-2020-11-175-193

\title{
Volunteering as forming factor of work-readiness for students of socially oriented specialization
}

\section{Valeriia Ovcharova}

Postgraduate of the Zaporizhzhia National University

$\triangle 66$, Zhukovskogo Str., Zaporizhzhia, Ukraine, 69600

E-mail: leraovcharova@gmail.com

ORCID: 0000-0003-4945-8138

Date of receipt of the article: April 14, 2020

Article accepted for publication: June 01, 2020

\section{Волонтерство як фактор формування професійної готовності студентів соціально-оріснтованих спеціальностей}

\section{Валерія Сергіївна Овчарова}

аспірантка Запорізького національного університету

$\checkmark$ вул. Жуковського 66, Запоріжжя, Україна, 69600

Дата надходження статті: 14 квітня 2020 p.

Стаття прийнята до друку: 01 червня 2020 p.

\section{Abstract}

Due to the situation with military conflict on the South-Eastern part of Ukraine, training of social workers who can effectively implement social policy is an acute issue. One of the characteristics of the social sphere specialist is work-readiness, which is a result of professional development and education in the university. Volunteering practices becomes one of the key components of vocational training for young specialists.

The research goal is to find out how participation in volunteer activities affects the formation of readiness of social work students for professional activities. 
An integrated questionnaire on the work-readiness of social work students has been developed for the study. The questionnaire has been based on the methodologies of questionnaire conduction by Eleonora Illaryonova and Nelli Menshykova (Illaryonova, Menshykova, 1991). It includes the following tasks for students: to answer closed and open questions, to complete sentences. The research covered 30 third- and fourth-year students of social work, the half of them practiced volunteering as the members of voluntary sector «Student's heart» (Zaporizhzhia) and the other one did not practice.

According to the study's result, students-volunteers have a positive attitude about their life, future, as well as high-level confidence that they have a professional skill more than students who did not practice volunteering. The study showed that volunteering had a positive impact on all components of student's work-readiness: «internal readiness», positive view of future, experience in social work practice. Moreover, we indicated the conditions under which the volunteer activities will contribute to the work-readiness: the system of education for volunteers, the link between the content of volunteer activities and chosen specialty, the demand-oriented character of volunteer activity. Taking into account these features in the organization of the student volunteer movement at university will give a qualitative and comprehensive effect of volunteering. The further research is planned to be devoted to the volunteering impact directly on the students' employment process, in particular the research among graduate students on determining the role of volunteer experience, skills, competencies and knowledge gained during volunteering, in their further employment.

Key words: volunteering, work-readiness, students, social work.

\section{References}

1. Bekh, I.D. (2003). Vykhovannia osobystosti (Vol. 2. Osobystisno oriientovanyi pidkhid : naukovo-praktychni zasady) [Education of the personality. (Vol. 2. Personality-oriented approach: scientific and practical principles)]. Kyiv : Lybid [in Ukrainian].

2. Bezpalko, O.V. (2005). Sotsialna robota $v$ hromadi : navch. posib [Social work in the community]. Kyiv : Tsentr navchalnoi literatury [in Ukrainian]. 
3. Dynamika mihratsiinykh nastroiv Ukraintsiv (rezultaty doslidzhennia sotsiolohichnoi hrupy «Reiynh») [Dynamics of migration sentiments of Ukrainians] Retrieved from http://ratinggroup. ua/research/ukraine/dinamika_migracionnyh_nastroeniy_ukraincev. html [in Ukrainian].

4. Karpenko, O.H. (2007). Profesiina pidhotovka sotsialnykh pratsivnykiv $v$ umovakh universytetskoi osvity : naukovo-metodychnyi ta orhanizatsiino-tekhnolohichnyi aspekt [Professional training of social workers in the conditions of university education]. Drohobych : Kolo [in Ukrainian].

5. Kapska, A.Y. (2010). Deiaki aspekty profesiinoi pidhotovky sotsialnykh pedahohiv i sotsialnykh pratsivnykiv [Some aspects of professional training of social pedagogues and social workers]. Visnyk Hlukhivskoho natsionalnoho pedahohichnoho universytetu im. O. Dovzhenka-Bulletin of Oleksandr Dovzhenko Hlukhiv National Pedagogical University named after A. Dovzhenko. Seriia : Pedahohichni nauky, 15, 12-16 [in Ukrainian].

6. Kapska, A.Y. (2005). Pidhotovka volonteriv do sotsialnoi roboty [Training of volunteers for social work]. Kyiv : Derzhsotssluzhba [in Ukrainian].

7. Koval, L.H., Zvierieva, I.D., Khliebik, S.R. (1997). Sotsialna pedahohika [Social pedagogy]. Kyiv : IZMN [in Ukrainian].

8. Kratinova, V.O., Larionova, N.B. \& Pesotska, O.P. (2006). Volonterstvo yak zasib sotsialnoho ta profesiinoho stanovlennia studentiv spetsialnostei «Sotsialna pedahohika» ta «Sotsialna robota». [Volunteering as a means of social and professional development of students of «Social pedagogy» and «Social work»]. Sotsialna pedahohika : teoriia ta praktyka - Social pedagogy : theory and practice, 6, 76-81 [in Ukrainian].

9. Rudiakevych, T.O.(Comp.).(2004). Orhanizatsiiavolonterskoho rukhu u vyshchykh navchalnykh zakladakh : Diahnostychnyi instrumentarii [Organization of the volunteer movement at higher educational institutions : Diagnostic tools]. Zhytomyr : ZhDU [in Ukrainian]. 
10. Zvierievoi, I. \& Laktionovoi, H. (Eds.). (2001). Pidhotovka volonteriv ta yikh rol $u$ realizatsii sotsialnykh proektiv [Training of volunteers and their role in the realization of social projects]. Kyiv : Nauk. svit [in Ukrainian].

11. Polishchuk, V.A. (2002). Kontseptualni zasady modeli pidhotovky sotsialno-pedahohichnykh kadriv v Ukraini [Conceptual principles of the model of socio-pedagogical staff training in Ukraine]. Visnyk Luhanskoho derzhavnoho pedahohichnoho un-tu im. T.Shevchenka-Bulletin of Luhansk Taras Shevchenko state pedagogical university, 11(55), 201-212 [in Ukrainian].

12. Prykhodko, Yu.O., Yurchenko, V.I. (2012). Psykholohichnyi slovnyk-dovidnyk [Psychological dictionary and reference book]. Kyiv : Karavela [in Ukrainian].

13. Andrushchenko V.P. et al. (2003). Sotsialna robota : Menedzhment sotsialnoi roboty [Social work : Management of social work]. Kyiv : DTsSSM [in Ukrainian].

14. Topol, O.I. (2011). Normatyvne ta navchalno-metodychne zabezpechennia pidhotovky sotsialnykh pratsivnykiv u vyshchykh navchalnykh zakladakh [Normative and educational-methodical support of social workers training at higher educational institutions]. Visnyk Chernihivskoho natsionalnoho pedahohichnoho universytetu im. T.H. Shevchenka [Bulletin of Taras Shevchenko Chernihiv National Pedagogical University], 90. Retrieved from http://chnpu.edu.ua/lib/ envoy/_pages/archive/2011/90/Topol.pdf [in Ukrainian].

15. Yants, N.D. (2009). Osnovy diialnosti volonteriv : kurs lektsii [Fundamentals of volunteers : a course of lectures]. PereiaslavKhmelnytskyi : PP «SKD» [in Ukrainian].

16. Bocharova, V.V. (1993). O nekotorykh metodolohycheskykh podkhodakh $k$ ponymanyiu tselostnoho protsessa sotsyalyzatsyy, vospytanyia y razvytyia lychnosty. Teoryia y praktyka sotsyalnoi raboty : otechestvennyi y zarubezhnyi opyt [About some methodological approaches to understanding the holistic process of socialization, education and personal development. Theory and practice of social work: domestic and foreign experience]. Moskva : Tula [in Russian]. 
17. Illaryonova, E.N. \& Menshykova, N.L. (1991). Kompleksnyj anketnyj test. Psihologicheskaja nauka : Problemy i perspektivy [Comprehensive questionnaire test. Psychological science : Problems and prospects]. Doklady Vsesojuznoj konferencii. Kyiv [in Ukrainian].

18. Kholostova, E.Y. (2001). Tekhnolohyy sotsyalnoi raboty [Technologies of social work]. Moskva : YNFRA [in Russian].

\section{Вступ}

Однією з важливих характеристик фахівця соціальної сфери $є$ його професійна готовність, яка $є$ результатом професійного розвитку під навчання в ВНЗ. Формування професійної готовності певною мірою залежить від того наскільки студент став суб'єктом освітнього процесу в ВНЗ - отримав досвід індивідуальноособистісної творчості тапрофесійної діяльності, сформував засади механізмів самореалізації, самоорганізації себе як професіонала. У цьому контексті, технології пов'язані з волонтерською діяльністю, можуть розглядатись як одні 3 ключових складових підготовки молодих фахівців. Волонтерство - це не тільки власне самовдосконалення, рефлексія та самореалізація, це й ресурс для накопичення професійного досвіду та перші спроби опанувати обрану професійну діяльність. Системне волонтерство сприяє більш «легкому» входженню студентів до практичної професійної діяльності, дозволяє отримати досвід спілкування з місцевими роботодавцями та побачити сферу майбутньої професійної діяльності «зсередини». Професійно готовий студент після закінчення ВНЗ вже краще знає i розуміс де він хоче і може працювати, i, завдяки волонтерській практиці, має більш чіткі уявлення щодо майбутньої професійної діяльності.

Враховуючи сучасну ситуацію 3 наявністю великої кількості внутрішньо-переміщенних осіб, воєнним конфліктом на Сході України, наша держава має значну потребу у фахівцях спеціальності «соціальна робота», здатних успішно реалізувати сучасні завдання соціальної політики, вільно володіти новими формами та методами соціальних досліджень, уміло використовувати на практиці 
ефективні технології практичної соціальної роботи з різними категоріями населення. Актуальність нашої статті підкріплюється сумною статистичною інформацією щодо міграційних настроїв молоді в пошуках роботи закордоном (Соціологічна група «Рейтинг», 2017). А саме, серед молоді (18-35 років) кількість тих, хто має бажання переїхати на постійне місце проживання за кордон, - 54 \%. У цьому контексті, слід зазначити, що волонтерство в освітньому процесі важливе не тільки як ресурс накопичення професійного досвіду та знайомство 3 потенційним місцем працевлаштування, але й ще і як механізм формування активної громадянської позиції та патріотизму.

Окреслена проблематика професійної підготовки молоді в соціальній сфері та волонтерства знайшла своє відображення у дослідженнях вітчизняних науковців. Зокрема, теоретикометодологічні аспекти професійної підготовки майбутніх соціальних працівників знайшли свій розгляд у роботах А.Й. Капської (2010), О.Г. Карпенко (2007), О.І. Тополі (2011) та інших. Деякі аспекти становлення соціального працівника як професіонала розкриті у наукових дослідженнях В. Бочарової (1993) та В. Поліщук (2002).

Аналіз наукових публікацій дає можливість визначити, що в роботах науковців волонтерство починає розглядатися як складова професійної підготовки. Бех І.Д. зазначає що, «важливо вчасно сформувати образ майбутньої професійної діяльності студентської молоді під час навчання та окреслити перспективу майбутнього життєвого шляху, насиченого подіями, творчою працею та масштабними задумами» (Бех, 2003: 48). Такі науковці як О.В. Безпалько (2005), Т.О. Рудякевич (2004), Є.І. Холостова (2001), Л.Г. Коваль (1997), Г.М. Лактіонова, І.Д. Звєрєва (2001) та інші акцентують увагу на ролі волонтерської діяльності в суспільстві, а зокрема і в соціальній роботі. Проаналізована наукова література з зазначеної тематики визначає сутність волонтерської діяльності та iï важливість у контексті соціального та професійного становлення соціального працівника. Але, на нашу думку, тема впли- 
ву волонтерської діяльності на формування саме професійної готовності студентів соціально орієнтованих спеціальностей в наукових працях та дослідженнях висвітлена недостатньо.

У нашій статті виявимо як участь у волонтерській діяльності впливає на формування готовності студентів спеціальності «соціальна робота» до професійної діяльності.

\section{Результати та їх обговорення}

Для реалізації поставлених цілей публікації вважаємо необхідним визначити зміст поняття «професійна готовність». В психологічному словнику поняття «професійна готовність» подається як «особистісна якість, яка має прояв в позитивній самооцінці себе як суб'єкта майбутньої професійної діяльності та прагненні займатися нею після закінчення ВНЗ» (Приходько, 2012). Вона допомагає молодому фахівцю успішно реалізовувати професійні функції, правильно використовувати набуті знання i досвід, зберігати самоконтроль і долати непередбачені перешкоди. Професійна готовність - вирішальна умова швидкої адаптації випускника до умов праці, подальшого його професійного вдосконалення і підвищення кваліфікації.

Таке розуміння професійної готовності дає можливість визначити іï зв'язок з рівнем професійної підготовки спеціаліста 3 соціальної роботи, який окрім високого рівня знань $з$ фаху включає особливо важливу для нас складову: практичний досвід роботи. Як правило, у вищих навчальних закладах набуття практичного досвіду роботи майбутнім фахівцем забезпечується за рахунок проходження навчальних та виробничих практик. Практика в такий спосіб є важливою складовою формування практичних навичок реалізації професійної діяльності, набуття першого досвіду побудови стосунків в організаціях та установах соціальної сфери. В той же час, основними проблемами у реалізації виробничих практик студентів безпосередньо на робочих місцях є по-перше те, що практикам відводиться незначна частина навчального навантаження у порівнянні з теоретичною підготовкою, і по-друге, студентам в процесі проходження цих практик, як правило, не надають 
достатньої можливості самостійно вирішувати певні професійні завдання, тобто виступати субєктами освітнього процесу. Виходячи 3 вищезазначеного, більша кількість студентів, отримавши освіту, є непідготовленими до здійснення практичної професійної діяльності, маючи переважно теоретичний обсяг знань.

Вирішити вищезазначену проблему, на наш погляд, допомагає залучення студентів у волонтерську діяльность. Теоретичні знання, отримані студентами під час навчання, безумовно, стануть основою їх професіоналізму, але при цьому важливо розвивати i особистісні якості студентів. Зайняття волонтерством вимагає виконання різноманітних практичних завдань, що сприяє формуванню професійно важливих якостей, практичних вмінь і навичок. Це дає можливість реалізувати дві взаємопов'язані цілі - саморозвиток студента як професіонала та особистості.

В такому аспекті ми можемо цілком погодитись 3 твердженням О. Карпенко: «формування професійної діяльності соціального працівника має здійснюватися на основі єдності теорії і практики навчання, реалізації у навчальній діяльності репродукції i творчості, раціонального і емоційного...» (Карпенко, 2007: 55). При цьому професійна підготовка майбутніх соціальних працівників має грунтуватися на основних дидактичних принципах (фундаментальності, системності, єдності логічного та історичного, єдності суспільного і особистісного, єдності теорії i практики), що дозволяє говорити про можливість створення педагогічної моделі професійної діяльності майбутнього соціального працівника (Карпенко, 2007: 56).

Важливими для нашого дослідження $є$ положення щодо важливості практичної підготовки фахівців, обгрунтовані А.Й. Капською. Дослідниця наголошує на тому, що «специфікою підготовки фахівця соціальної та соціально-педагогічної сфери має стати збільшення годин на проведення занять в польових умовах (соціальні служби різного типу, неурядові організації, притулки, дружні клініки для молоді тощо)» (Капська, 2010: 14). Крім того, досліджуючи тему професійної підготовки соціальних 
працівників, вона вказує на значущість волонтерства у підготовці майбутніх абітурієнтів до вибраної ними спеціальності «соціальна робота» шляхом створення шкіл волонтерів у загальноосвітніх закладах. Дослідниця звертає увагу на диференційованість форм вступних випробувань, і пропонує надавати перевагу тим особам, які мають досвід волонтерської діяльності.

Погоджуємось 3 авторським колективом вчених А.Й. Капською, О.Г. Карпенко, Н.М. Комаровою, що у студентів-волонтерів мотиви добровільної соціальної роботи специфічні: насамперед їх цікавлять професійні проблеми (Капська та інш., 2005). Вони можуть бути як формальними - одержання заліку, проходження практики, так і реальними - набуття фахових знань з майбутньої спеціальності, напрацювання навичок спілкування 3 клієнтами. Для студентів дуже важливим є спілкування з професіоналами, знайомство зі всим, що може їм допомогти у подальшому стати висококваліфікованими фахівцями і працевлаштуватись.

Успішне формування професійної готовності відбувається при активізації наступних факторів: забезпечення свідомого ставлення майбутнього фахівця до роботи з формування професійних навичок; здійснення тісного зв’язку теорії з практикою; озброєння майбутнього соціального працівника необхідними знаннями про специфіку діяльності соціальних працівників; організації систематичної практики. Деякі з цих завдань можна вирішити шляхом організації волонтерської діяльності в навчальних закладах.

Активний розвиток волонтерського руху спостерігається серед студентів українських вищих навчальних закладів. Для прикладу, в наукових працях можна знайти опис функціонування волонтерського студентського руху «СОВА» (Рудякивич, 2004), волонтерського загону з студентів на базі Чернівецького обласного Центру соціальних служб для сім’ї, дітей та молоді (Кратінова та інш., 2006), студентів-волонтерів м. Луцьк (Янц, 2009).

Яскравим прикладом організації студентами волонтерського руху є волонтерський сектор «Студентське серце», який був організований в 2007 році в межах розвитку студентського само- 
врядування на факультеті соціології та управління Запорізького національного університету. До складу сектору входять студенти різних курсів спеціальностей «соціальна робота», «політологія» та «соціологія», але, звичайно, що більшою мірою волонтерами $\epsilon$ представники спеціальності «соціальна робота». До основних цілей волонтерського сектору можна віднести підтримку та допомогу соціально незахищеним верствам населення, а також допомогу студентам отримати практичний досвід, що дозволяє бути готовим до працевлаштування. В межах діяльності волонтерського сектору створена система підготовки волонтерів - «Школа волонтера», на якій майбутні волонтери отримують знання щодо етики волонтерської діяльності, профілактики «вигорання» волонтера, актуалізують власні мотиви волонтерської діяльності та знайомляться 3 актуальним переліком міжнародних волонтерських програм та можливостями волонтерської участі в Україні. 3 метою заохочення волонтерів передбачені такі засоби винагородження як нарахування додаткових балів за самостійну роботу, видача Волонтерської книжки, яка слугує аналогом трудової книжки. Волонтерська книжка виступає механізмом фіксації досвіду участі студента у волонтерській діяльності, який можна буде презентувати роботодавцю при подальшому працевлаштуванні.

Процес формування професійної готовності можна визначити як динамічний, а його особливістю є комплексний характер. Це обумовлено тим, що особистість формується в цілому, а не по частинах, а розвиток певних рис характеру і якостей йде одночасно, в комплексі. Формування професійної готовності у студентів до соціальної роботи пов'язане з вирішенням основного протиріччя між досягнутим розвитком студентів та тими вимогами, які до них висуває специфіка професійної діяльності. Однією 3 умов його вирішення $€$ самоствердження, самоактуалізація студента спеціальності «соціальна робота».

У зазначеному контексті, волонтерство виступає як раз тією діяльністю, що допомагає студенту реалізувати процеси самоствердження та самоактуалізації, а ще й паралельно, залежно від 
специфіки волонтерювання, набути професійного досвіду та сформувати професійну готовність. Для того, щоб довести вищесказане, нами було проведено дослідження з визначення впливу досвіду волонтерства студентів на формування професійної готовності.

Для проведення дослідження нами була використана модифікована комплексна анкета 3 вивчення професійної готовності студента спеціальності «соціальна робота», яка грунтувалась на анкетному тесті, розробленому та обгрунтованому в наукових працях Ілларіонової Е.М та Меньшикової Н.Л (Ілларіонова, Меньшикова, 1991). Анкета включає виконання студентами таких завдань: дати відповідь на закриті та відкриті запитання, закінчити незавершені речення.

Вище ми зазначали, що на професійну готовність впливає не тільки наявний професійний досвід та обсяг теоретичних знань. Уявлення щодо власного майбутнього, сприйняття зовнішнього світу також впливають на формування професійної готовності. Тому анкета для дослідження складалась 3 двох частин. Частина I присвячена порівняльному аналізу уявлень про себе, своє життя та майбутнє у студентів-волонтерів та студентів, що не займаються волонтерською діяльністю. Виявлення цих уявлень має на меті вивчення досліджуваної проблеми в розширеному контексті. Шляхом методу порівняння були визначені відмінності та спільності між групами студентів (волонтери-неволонтери) щодо уявлень про себе, власне життя, майбутнє. Для дослідження впливу волонтерської діяльності на уявлення людини про іï життя були співставленні відповіді та результати виконання завдань.

Частина II має на меті визначити відношення студентів до волонтерської діяльності та обраної спеціальності, розуміння свого рівня професійної підготовки та роль волонтерства в формуванні останнього на думку самих волонтерів. Ми визначили низку індикаторів, за які передбачають наявність професійної готовності: бажання працювати за обраною спеціальністю, відзначення у себе наявності професійного досвіду, внутрішнє сприйняття власної професійної готовності. Визначення впливу волонтерської 
діяльності на формування професійної готовності відбувалося за такими показниками: наявність досвіду волонтерства, що відповідає обраній спеціальності та його частота, пов’язування волонтерства 3 отриманням професійного досвіду та професійноважливих якостей, досвіду спілкування з роботодавцями, , визначення важливості волонтерства у системі формування професійної готовності на думку студентів. Збір результатів відбувався шляхом отримання відповідей на запитання.

Дослідження охоплювало 30 студентів 3 та 4 курсу освітньокваліфікаційного рівня бакалавр спеціальності «соціальна робота», половина 3 яких практикує волонтерство та є членами волонтерського сектору «Студентське серце» (м.Запоріжжя). Згідно результатів дослідження, студенти, які займаються волонтерською діяльністю мають показники позитивних уявлень про власне життя в більшій кількості, ніж ті студенти, що не займаються волонтерською діяльністю. Це проявляється у тому, що студенти, що займаються волонтерською діяльністю, відзначили, що більшою мірою переживають успіх у своєму житті, ніж ті, що не займаються волонтерством. Студенти, які займаються волонтерською діяльністю мають позитивні характеристики майбутнього, віру в власні можливості та готовність до розвитку. Студенти, що не займаються волонтерством, у своїх відповідях більш схильні до характеристик неоднозначності стосовно власного майбутнього. У відповідях на питання стосовно власного професійного майбутнього студенти, які займаються волонтерською діяльністю, показали більш чіткі уявлення про те, де вони хочуть працювати і 3 якою категорією клієнтів. Студенти, які не займаються волонтерством, у своїх відповідях в більшій мірі орієнтовані на терміни пошуку роботи і не торкаються моментів особливостей професійної діяльності. На жаль, межі даної статті не дають нам змогу детального висвітлити всі результати дослідження, але виходячи 3 теми нашої статті більш детально зупинимося на розгляді відповідей на питання другої частини анкети, та наведемо в Таблиці 1 деякі 3 них. 
Таблиия 1

Відношення студентів до волонтерської діяльності

\begin{tabular}{|c|c|c|c|}
\hline \multirow{2}{*}{\multicolumn{2}{|c|}{ Твердження }} & \multicolumn{2}{|c|}{$\begin{array}{c}\text { Кількість позитивних } \\
\text { відповідей (у\%) }\end{array}$} \\
\hline & & Волонтер & Не волонтер \\
\hline \multicolumn{2}{|c|}{ Бажання працювати за фахом } & $86,7 \%$ & $46,7 \%$ \\
\hline \multirow{3}{*}{$\begin{array}{l}\text { Джерело отримання } \\
\text { досвіду роботи }\end{array}$} & Волонтертсво & $86,7 \%$ & - \\
\hline & Практика від ВН3 & $60 \%$ & $40 \%$ \\
\hline & Підробітки & $6,7 \%$ & - \\
\hline \multirow{3}{*}{$\begin{array}{l}\text { Ознайомлення } \\
\begin{array}{l}\text { практичними } \\
\text { діяльності } \\
\text { працівника }\end{array}\end{array}$} & Повністю ознайомлений & $20 \%$ & - \\
\hline & Частково ознайомлений & $73,3 \%$ & $26,7 \%$ \\
\hline & $\begin{array}{l}\text { Ознайомлений в межах } \\
\text { теоретичної підготовки в } \\
\text { ВН3 }\end{array}$ & $6,7 \%$ & $73,3 \%$ \\
\hline \multirow{4}{*}{$\begin{array}{lr}\text { Джерело } & \text { отримання } \\
\text { професійно } & \text { важливих } \\
\text { якостей } & \end{array}$} & Волонтерство & $73,3 \%$ & - \\
\hline & Практика від ВН3 & $53,3 \%$ & $86,7 \%$ \\
\hline & Теоретична підготовка ВНЗ & $13,3 \%$ & $53,3 \%$ \\
\hline & Підробітки & $6,7 \%$ & - \\
\hline \multicolumn{2}{|c|}{ Усвідомлене почуття професійної готовності } & $26,7 \%$ & $13,3 \%$ \\
\hline \multicolumn{2}{|c|}{$\begin{array}{l}\text { Розуміння волонтерства } \\
\text { професійних якостей. }\end{array}$} & $100 \%$ & $20 \%$ \\
\hline
\end{tabular}

Відповіді на питання про ознайомлення 3 практичними аспектами діяльності соціального працівника дають змогу нам проаналізувати рівень розуміння студентами специфіки практичної професійної діяльності соціального працівника. Отже, 20\% волонтерів зазначають, що вони повністю ознайомлені з практичними аспектами діяльності соціального працівника, а тому можна казати про те, що вони вже виступали в ролі соціальних працівників та виконували їх професійні обов'язки. Серед студентів-не волонтерів не має жодного позитивного твердження про повне ознайомлення 3 професійною діяльністю соціального працівника, це дає змогу говорити нам про те, що студенти-неволонтери не відчувають суб'єктивної впевненості в своїх знаннях, практичних навичках та вміннях.

Досліджуючи рівень усвідомленої професійної готовності, були отримані дані про те, що волонтери в більшій мірі готові до практичної діяльності (26,7\%) ніж студенти, що не займаються волонтерською діяльністю ( 13,3\%). Розуміння волонтерства як джерела отримання професійно-важливого досвіду та практичних на- 
вичок і якостей властиве всім волонтерам, та лише 20 \% студентам, що не займаються волонтерською діяльністю. Можна зробити висновки про те, що користь від волонтерства і розуміння важливості цієї діяльності властиве тільки студентам, що займаються волонтерством. Студенти, які не займалися волонтерською діяльністю в більшій мірі зазначають те, що волонтерство не є важливим для їх професійного становлення.

Отже, аналізуючи результати другої частини анкетного тесту, можемо зробити висновки: студенти - волонтери мають порівняно більше бажання працювати за фахом, вони відчувають більший досвід роботи в соціальній сфері у себе, та отримання цього досвіду вони пов'язують з волонтерством. Студенти, що не займалися волонтерською діяльністю зазначають, що їх досвід роботи в соціальній сфері був отриманий лише в межах практичної діяльності від ВНЗ. 3 такими результатами ми з впевненістю можемо стверджувати те, що волонтерство впливає на складові професійної готовності студентів - внутрішню готовність, сформованість уявлень про власне майбутнє та наявність досвіду практичної соціальної роботи.

Для того, щоб волонтерство виступало джерелом формування професійної готовності студента, слід звернути увагу на деякі особливості:

- організувати систему підготовки волонтерів, яка будезаснована на інтеграції навчально-виховного процесу ВНЗ та інтенсивних методів соціально-психологічного навчання, які сприяють одночасно оволодінню технологіями професійної діяльності, навичками їх застосування на практиці та розвитку особистості студента;

- волонтерська діяльність, яку практикують студенти, повинна відповідати вимогам професійної діяльності та входити в сферу соціальної роботи;

- бажано, що суб'єктом системної волонтерської діяльності виступав студент, що пройшов підготовку та свідомо вмотивований на отримання професійного досвіду шляхом реалізації волонтерської діяльності. 
Отже, все зводиться до формування моделі організації волонтерської діяльності у вищому навчальному закладі, яка включала б ефективні механізми залучення та відбору, навчання та моніторингу, підтримки та заохочення, що є основними елементами й етапами діяльності волонтерів.

\section{Висновки}

За результатами нашого дослідження можна стверджувати, що волонтерство $є$ фактором формування професійної готовності студентів соціально-орієнтованих спеціальностей. Волонтерська діяльність формує впевненість в власному позитивному майбутньому, у власному виборі професійної діяльності, є ресурсом отримання досвіду роботи, що відповідає спеціальності. Також ми зазначили за яких умов організована волонтерська діяльність студентів буде сприяти формуванню професійної готовності. Врахування цих особливостей при організації студентського волонтерського руху в ВНЗ буде давати якісний та комплексний ефект від волонтерської діяльності. В подальших дослідженнях ми плануємо розглянути вплив волонтерства безпосереднього на процес працевлаштування студентів, зокрема провести дослідження серед студентів-випускників (в яких наявний та відсутній досвід волонтерської діяльності) та визначити роль волонтерського досвіду, сформованих навичок, компетенцій та отриманих знань протягом реалізації волонтерської діяльності у процесі їх подальшого працевлаштування.

\section{Література}

1. Бех І.Д. Виховання особистості : У 2 кн. Кн. 2 : Особистісно орієнтований підхід : науково-практичні засади : навч.-метод. посіб. Київ : Либідь, 2003. 344 с.

2. Безпалько О.В. Соиіальна робота в громаді : навч. посіб. Київ : Центр навчальної літератури, 2005. 176 с.

3. Динаміка міграційних настроїв Українців (результати дослідження соціологічної групи «Рейинг»). URL: http://ratinggroup. ua/research/ukraine/dinamika_migracionnyh_nastroeniy_ukraincev. html (Дата звернення 15.11.2019). 
4. Карпенко О.Г. Професійна підготовка соиіальних працівників в умовах університетської освіти : науковометодичний та організаційно-технологічний аспект : монографія. Дрогобич : Коло, 2007. 374 с.

5. Капська А.Й. Деякі аспекти професійної підготовки соціальних педагогів i соціальних працівників. Вісник Глухівського начіонального педагогічного університету ім. О. Довженка. Серія : Педагогічні науки. 2010. №15. С. 12-16.

6. Капська А.Й. Підготовка волонтерів до соиіальної робо$m и$ : навч.-метод. посібник. Київ : Держсоцслужба, 2005. 152 с.

7. Коваль Л.Г., Звєрєва І.Д., Хлєбік С.Р. Соиіальна педагогіка : навч. посіб. Київ : ІЗМН, 1997. 392 с.

8. Кратінова В.О., Ларіонова Н.Б., Песоцька О.П., Волонтерство як засіб соціального та професійного становлення студентів спеціальностей «Соціальна педагогіка» та «Соціальна робота». Соціальна педагогіка : теорія та практика. 2006. № 6. С. 76-81.

9. Організація волонтерського руху у вищих навчальних закладах : Діагностичний інструментарій : метод. розроб. / Укл. Т.О. Рудякевич. Житомир : ЖДУ, 2004. 20 с.

10. Підготовка волонтерів та їх роль у реалізаиї̈ соиіальних проектів : метод. посіб. / Під заг. ред. : І. Звєрєвої, Г. Лактіонової. Київ : Наук. світ, 2001. 49 с.

11. Поліщук В.А. Концептуальні засади моделі підготовки соціально-педагогічних кадрів в Україні. Вісник Луганського державного педагогічного ун-ту ім. Т. Шевченка. 2002. №11(55). C. $201-212$

12. Приходько Ю.О., Юрченко В.І. Психологічний словникдовідник : навч. посіб. Київ : Каравела, 2012. 328 с.

13. Соиіальна робота : Менеджмент соиіальної роботи : навч. посіб. / Андрущенко В.П. та інш. Київ : ДЦССМ, 2003. $372 \mathrm{c}$.

14. Тополь O.I. Нормативне та навчально-методичне забезпечення підготовки соціальних працівників у вищих навчальних закладах. Вісник Чернігівського начіонального педагогічного 
університету ім. Т.Г. Шевченка. 2011. № 90. URL: http://chnpu. edu.ua/lib/_envoy/_pages/archive/2011/90/Topol.pdf.

15. Янц Н.Д. Основи діяльності волонтерів : курс лекцій. Переяслав-Хмельницький: ПП «СКД», 2009. 200 с.

16. Бочарова В.В. О некоторых методологических подходах $\kappa$ пониманию целостного процесса социализаџии, воспитания и развития личности. Теория и практика сочиальной работы : отечественный и зарубежный опыт. Москва : Тула, 1993.

17. Илларионова Э.Н, Меньшикова Н.Л. Комплексный анкетный тест. Психологическая наука : Проблемы и перспективы. Доклады Всесоюзной конференции. Киев. 1991. С. 76-81.

18. Холостова Е.И. Технологии соииальной работы. Москва : ИНФРА, 2001. 400 c.

\section{Овчарова B.C.}

\section{Волонтерство як фактор формування професійної готовності студентів соціально-оріснтованих спеціальностей}

\section{Анотація}

Враховуючи сучасну ситуацію з наявністю великої кількості внутрішньо-переміщенних осіб та воєнним конфліктом на Сході України, наша держава має значну потребу у фахівцях спеціальності «соціальна робота», здатних успішно реалізувати актуальні завдання соціальної політики. Однією з важливих характеристик фахівця соціальної сфери є його професійна готовність, яка $\epsilon$ результатом професійного розвитку та навчання в ВНЗ. Технології пов'язані з волонтерською діяльністю, стають однією 3 ключових складових підготовки молодих фахівців. У нашій статті ми виявили як участь у волонтерській діяльності впливає на формування готовності студентів спеціальності «соціальна робота» до професійної діяльності. Для того, щоб з'ясувати вищесказане, нами було проведено дослідження з визначення впливу досвіду волонтерства студентів на формування професійної 
готовності. Для проведення дослідження нами була розроблена комплексна анкета 3 вивчення професійної готовності студента спеціальності «соціальна робота», яка грунтувалась на методиках проведення анкетного тесту в наукових працях Ілларіонової Е.M та Меньшикової Н.Л (Іларіонова, Меньшикова, 1991). Анкета включає виконання студентами таких завдань: дати відповідь на закриті та відкриті запитання, закінчити незавершені речення. Дослідження охоплювало 30 студентів третього та четвертого курсу спеціальності «соціальна робота», половина 3 яких практикує волонтерство та $є$ членами волонтерського сектору «Студентське серце» (м.Запоріжжя). Згідно результатів дослідження, студенти, які займаються волонтерською діяльністю мають показники позитивних уявлень про власне життя а також вищий рівень вневненості в оволодінні професійними навичками, ніж ті студенти, що не займаються волонтерською діяльністю. Результати дослідження показали, що волонтерство позитивно впливає на складові професійної готовності студентів - внутрішню готовність, сформованість уявлень про власне майбутнє та наявність досвіду практичної соціальної роботи. Також ми зазначили за яких умов організована волонтерська діяльність студентів буде сприяти формуванню професійної готовності: організація системи підготовки волонтерів, відповідність змісту волонтерської діяльності обраній спеціальності, суб'єктно-орієнтований характер.

Ключові слова: волонтерство, професійна готовність, студенти, соціальна робота

\section{Овчарова B.C.}

\section{Волонтерство как фактор профессиональной готовности сту- дентов социально-ориентированных специальностей}

\section{Аннотация}

Одной из важных характеристик специалиста социальной сферы является его профессиональная готовность, которая являет- 
ся результатом профессионального развития и обучения в учебном заведении. В статье мы выяснили как участие в волонтерской деятельности влияет на формирование готовности студентов специальности «социальная работа» к профессиональной деятельности. Для проведения исследования нами была разработана комплексная анкета по изучению профессиональной готовности студента специальности «социальная работа», которая основывалась на научных трудах Илларионовой Э.Н. и Меньшиковой Н.Л. о методиках проведения анкетного теста (Илларионова, Меньшикова, 1991). В исследовании приняло участие 30 студентов специальности «социальная работа», половина из которых практиковали волонтерство во время обучения. Результаты исследования показали, что волонтерство положительно влияет на все составляющие профессиональной готовности студентов - внутреннюю готовность, сформированность представлений о собственном будущем и наличие опыта социальной работы. Также мы определили при каких условиях организована волонтерская деятельность студентов будет способствовать формированию профессиональной готовности.

Ключевые слова: волонтерство, профессиональная готовность, студенты, социальная работа 